Abstracta Iranica Abstracta Iranica

Revue bibliographique pour le domaine irano-aryen

Volume 23 | 2002

Comptes rendus des publications de 2000

\title{
Mokālemāt : goftegū bā Ebrāhìm Amīrī. Tehrān, Vīstār, 1379/2000, 296 p. [Entretiens]
}

\section{Christophe Balaÿ}

\section{(2) OpenEdition}

1 Journals

Édition électronique

URL : http://journals.openedition.org/abstractairanica/35891

DOI : 10.4000/abstractairanica.35891

ISSN : 1961-960X

\section{Éditeur :}

CNRS (UMR 7528 Mondes iraniens et indiens), Éditions de l'IFRI

\section{Édition imprimée}

Date de publication : 15 mai 2002

ISSN : 0240-8910

\section{Référence électronique}

Christophe Balaÿ, « Mokālemāt : goftegū bā Ebrāhīm Amīrī. Tehrān, Vìstār, 1379/2000, 296 p.

[Entretiens] », Abstracta Iranica [En ligne], Volume 23 | 2002, document 323, mis en ligne le 08 février 2010, consulté le 25 septembre 2020. URL : http://journals.openedition.org/abstractairanica/35891 DOI : https://doi.org/10.4000/abstractairanica.35891

Ce document a été généré automatiquement le 25 septembre 2020.

Tous droits réservés 


\title{
Mokālemāt : goftegū bā Ebrāhìm Amīrī. Tehrān, Vīstār, 1379/2000, 296 p. [Entretiens]
}

\author{
Christophe Balaÿ
}

1 Autant qu'on puisse en juger d'après les renseignements incomplets fournis par cette édition, ce serait la deuxième (quoiqu'elle soit annoncée première) ou tout au moins la deuxième version corrigée et augmentée d'un texte lui-même re-composé par A. Rādī à partir de 800 pages d'un manuscrit établi par Amīrī au moyen de 21 cassettes enregistrées pendant trois mois d'entretiens à la fin des années 80 . La première préface porte la date de 1368/1989; la deuxième 19 esfand 1977/1998. Les entretiens avec Rādī (né le 10 mehr 1318), dramaturge, se répartissent en 17 chapitres plus ou moins organisés. Rādī passe en revue les grandes étapes de sa vie depuis sa jeunesse à Ra.t puis à Téhéran; il évoque aussi ses premiers essais d'écriture. A travers ces souvenirs, c'est toute une génération d'écrivains comme B. Beyḍā'ī, M. A. Sepānlū, A. Redāa Aḥmadī, N. Šāhīnpar ou encore Esmā̄îl Nūrī 'Alā' qui défile dans la mémoire de l'écrivain. A. Rādī raconte comment il est passé du récit à la scène et il décrit longuement et en détails les difficultés propres au métier d'auteur dramatique. Il évoque ensuite l'influence de Tchekhov, puis donne son point de vue sur la critique littéraire contemporaine. Pour finir, il décrit un phénomène post-révolutionnaire : la fuite des gens de théâtre vers le cinéma. L'image se substitue à la parole probablement plus dangereuse. Index. Pas de bibliographie.

\section{INDEX}

Thèmes : 11.1.2. Littérature persane moderne 
AUTEURS

CHRISTOPHE BALAŸ

IFRI - Téhéran 